\title{
The Costochondral Junction During Later Stages of Intrauterine Life, and Abnormal Growth Patterns Found in Association with Perinatal Death
}

\author{
JOHN L. EMERY and PITSA K. KALPAKTSOGLOU \\ From the Taylor Research Laboratories, Children's Hospital, Western Bank, Sheffield 10
}

The classic work of Harris (1933) and later clinicopathological studies of Follis and Park (Park and Richter, 1953; Park, 1954; McCollum, Simmonds, Shipley, and Park, 1922) laid the foundation for our knowledge of bone growth, not only in health but also in a number of nutritional diseases of childhood (Follis, 1958). They were able to relate the histological findings in the long bones to the radiological picture. Park's Goldberg Lecture of 1962 (Park, 1964) is a magnificent summary of the way in which general nutritional disturbances in the growth of a child leave lasting effects on the structure of bones. Most of the work on rickets, and indeed on most bone diseases, has been done on the lower end of the humerus and head of the radius, probably because these are the sites where radiological changes are usually sought and found.

Some 15 years ago, we first began using the observations of Park on the effect of general nutritional disease as a means of assessing the previous health of children found unexpectedly dead (Emery, 1964). We first confirmed the observations of Park and Follis on older children, that arrest lines are most obvious in the ribs, and we found that the costochondral junction of the 4th, 5th, or 6th rib often showed manifestations of alteration in growth rate, which were not visible when the growing points of the limb bones were examined. We then attempted to apply the same type of criteria to the costochondral junction in all perinatal deaths. This was an attempt to obtain from the costochondral junction something of the same type of history of intrauterine disease that one is able to read from the end of a bone for a child's postnatal diseases at the age of 1 year.

The rib is an ideal bone for studying linear growth, being probably the most rapidly growing bone in a linear fashion throughout the whole of intrauterine

Received May 31, 1966. life. The costochondral junction appears as a column of cartilage cells sitting between regular strands of matrix and standing on bony trabeculae. It has a rather static architectural appearance. This gives a completely false concept. The length of a 5 th or 6 th rib at birth is approximately $120 \mathrm{~mm}$. It has reached this length in considerably under 280 days, this is at a rate of over $0.43 \mathrm{~mm}$. per day which implies a growth of $0.22 \mathrm{~mm}$. $(220 \mu)$, at each end, a day. The depth of a cartilaginous cell at the costochondral junction is approximately $14 \mu$. If we suppose that only a half of the increased length of the rib comes from the growth of the costochondral junction, this means that a column 16 cells in depth-almost the whole of the large ballooned cartilaginous cells-are being completely replaced each day. Thus, the costochondral junction should really be considered more like a slow-firing multibarrelled rocket! Packets of cartilage cells are being pushed daily into the barrels of matrix. The cartilage cells blow up into columns and 'explode' into the bone cavity, 'pushing' the cartilage cavity further away from the bone, and leaving a sort of slip-stream of matrix behind.

Ten years ago, we established criteria for normality and abnormality of the costochondral junction for the foetus and newborn, and, after the study of about 500 costochondral junctions, our criteria were presented to the Pathological Society (Emery, 1957). Since that time, we have had the opportunity of examining over 5000 costochondral junctions from perinatal and child deaths. This has confirmed our original concepts of the normal appearances (Fig. 1), and our conviction that the routine study of the costochondral junction is one of the most valuable examinations that can be carried out in perinatal pathology.

This paper is concerned with three objectives.

(1). A description of the appearance of the normal costochondral junction at birth and during the latter third of intrauterine life. 

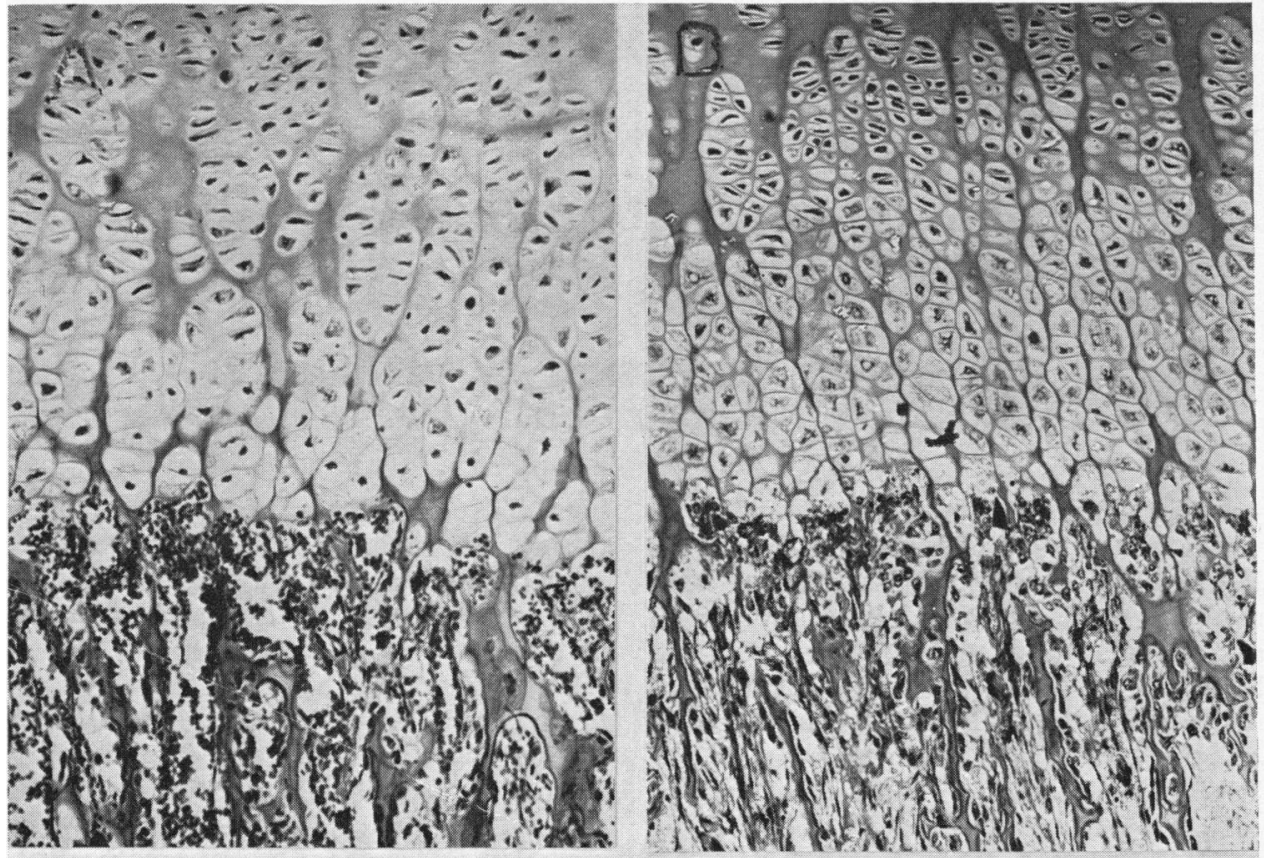

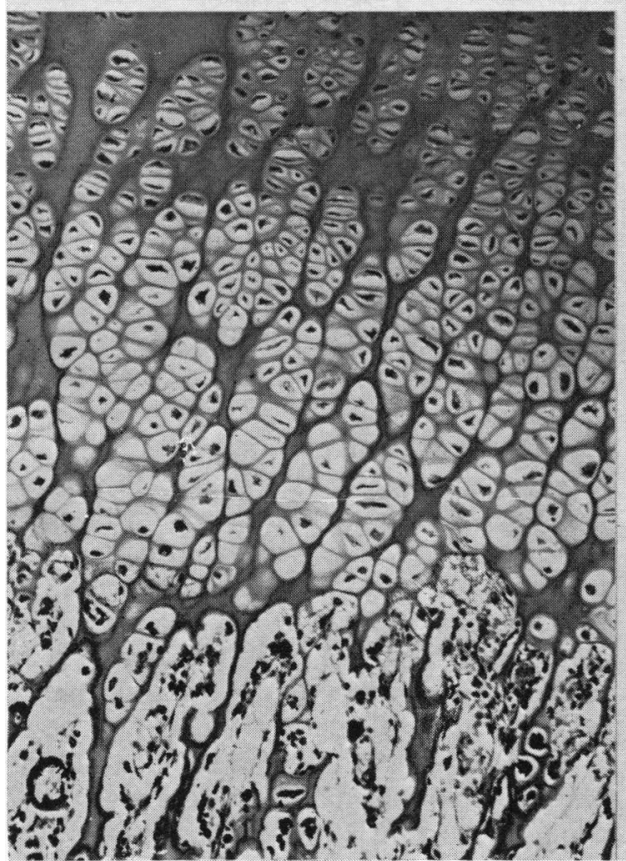

C

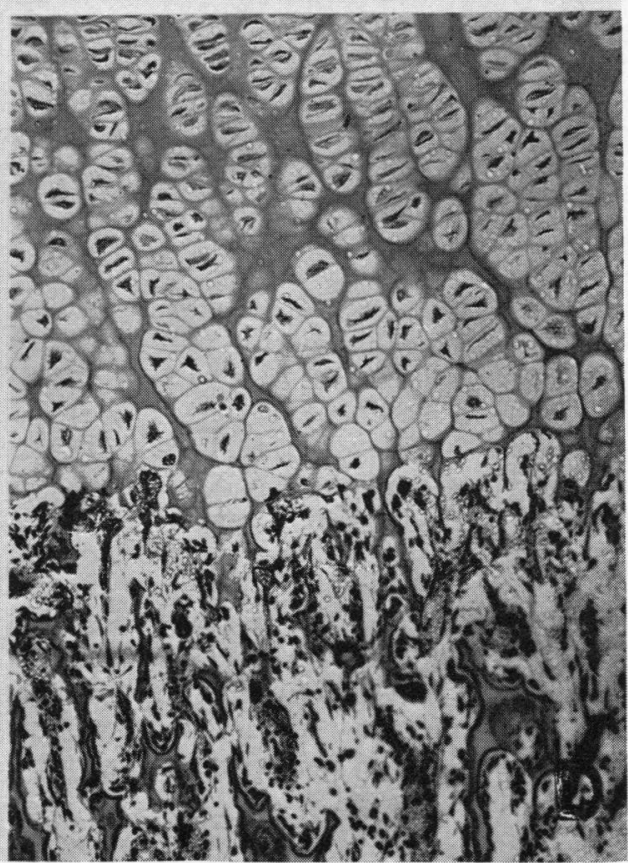

$D$

FIG. 1.-Showing the normal appearance of the costochondral junction at different gestational periods: (A) 20/24 weeks; (B) 30/32 weeks; $(C) 36 / 37$ weeks; $(D) 40 / 41$ weeks. (Massons trichrome. $\times 140$.) 
(2). A description of some of the abnormalities found in the growing end of the rib in the same age period.

(3). An assessment of the incidence and importance of intrauterine disease in perinatal deaths.

\section{Material and Methods}

It has been the routine practice at the Children's Hospital, Sheffield, to take the 4th and 5th ribs at all necropsies for the histological study of the costochondral junction and bone-marrow.

Handling the rib. The technique used is as follows. The cartilage is severed at about $1 \mathrm{~cm}$. from the bone while opening the thoracic cavity. After the intercostal muscles have been divided, the rib is cut with a pair of bone forceps at a distance of between 3 to $5 \mathrm{~cm}$. from the cartilage, depending on the size of the child. The ribs are then fixed in $10 \%$ formal saline for 2 to 10 days. At the end of this time the shreds of muscle are removed and, using a sharp new disposable scalpel blade, the distended lateral corners of the costochondral junction are cut off, the cut going from the cartilage to the bone. This exposes the marrow cavity and costochondral junction on both sides. No attempt is made to cut down the hard long rib. The rib is then fixed for a further week and then decalcified in 5\% nitric acid.

After decalcification, the shaft of the rib is trimmed off to a distance of approximately $2 \mathrm{~cm}$. from the cartilage. The rib is processed and blocked on its cut surface and cut away before taking the sections for staining, until the whole of the medulla has been exposed and the sections judged to be in the centre of the shaft.

This timing and handling technique is essential, for, if the rib is split open at the time of necropsy, or an attempt is made to cut it in the mid-line even after decalcifying, it is extremely easy to distort and rupture the costochondral junction. The rib sections are first stained by the Masson trichrome method.

Cases studied. The costochondral junction has been examined in a series of over 5000 necropsies on children during the past 15 years. These children comprised approximately $90 \%$ of the neonatal and child deaths in the city of Sheffield, excluding only deaths in one of the University maternity hospitals.

The concept of normal cases was obtained from the study of tissue from children dying truly accidental deaths: there are really only two causes for such deathsone from vasa praeviae and the other from women who had been killed in motor accidents. The latter infants were made available to us by our forensic medical colleagues.

A separate series of ribs was made available during the Perinatal Mortality Survey of 1959 (Butler and Bonham, 1961, 1963), when pathologists from many centres in the country sent us ribs from their necropsies. By this means 500 ribs became available. These ribs were kept separate from the home ribs and have been studied and analysed separately, as they formed an external control population of perinatal deaths.

For the purposes of this study, ribs were only used from children dying within 7 days of birth and for whom a history of reasonable accuracy was available for the purpose of assessing gestational age, and in which autolytic or other artefects had not made study of the rib likely to be inaccurate.

Method of study. Criteria of measurement of the costochondral junction were drawn up both for normal and abnormal structure. These are set out below and summarized in Table I.

General form of line. The costochondral junction of an adult rib forms an almost straight line directly across the rib. This is not so in the foetus, particularly in the centre of the cartilage where, contrary to the view of Harris (1929), a large vessel runs directly between the bone and the cartilage. The lines of junction, as seen in the low power of the microscope, were thus: (a) straight (ignoring the central vessel) (Fig. 2); (b) convex, usually forming a type of meniscus; (c) irregular, where a definite tissue junction could be seen in some areas but not forming any definite line or pattern (Fig. 1C); (d) indistinct, where no definite line was seen (Fig. 3 and 4A).

General form of cartilage. The cartilage can be easily divided into three zones, and these have been used by most workers, though using slightly differing terminologies.

TABLE I

Grouping and Histological Criteria for the Ribs

\begin{tabular}{|c|c|c|c|c|c|}
\hline & & & Normal & Cessation & Bizarre \\
\hline $\begin{array}{l}\text { Junctional line } \\
\text { Cartilage colum } \\
\text { Thickness of zo } \\
\text { Thickness of zo } \\
\text { Bridging } \quad \text {. } \\
\text { Banding } \\
\text { Matrix pools }\end{array}$ & $\begin{array}{l}\cdots \\
\dot{\mathbf{I}} \\
\mathbf{I I} \\
\cdots \\
\cdots\end{array}$ & \begin{tabular}{l|}
$\cdots$ \\
$\cdots$ \\
$\cdots$ \\
$\cdots$ \\
$\cdots$ \\
$\cdots$
\end{tabular} & $\begin{array}{l}\text { Recognizable } \\
\text { Compound/simple, straight } \\
0 \cdot 03-0 \cdot 04 \mathrm{~mm} \text {. } \\
0 \cdot 06-0.09 \mathrm{~mm} \text {. } \\
\text { Minimal } \\
\text { Absent } \\
\text { Few }\end{array}$ & $\begin{array}{l}\text { Definite } \\
\text { Simple/compound, straight } \\
\text { Reduced } \\
\text { Normal or reduced } \\
\text { Present } \\
\text { Present } \\
\text { Variable }\end{array}$ & $\begin{array}{l}\text { Indefinite } \\
\text { Irregular, compound, complex } \\
\text { Increased or normal } \\
\text { Very variable } \\
\text { Present } \\
\text { Present } \\
\text { Many, irregular }\end{array}$ \\
\hline History & $\cdots$ & $\cdots$ & $\begin{array}{l}\text { Sudden or unexpected death; } \\
\text { history compatible with } \\
\text { normality; no dysmaturity } \\
\text { or toxaemia }\end{array}$ & $\begin{array}{l}\text { Very variable; (often repeated } \\
\text { perinatal deaths) }\end{array}$ & Variable; (often 'toxaemic') \\
\hline
\end{tabular}




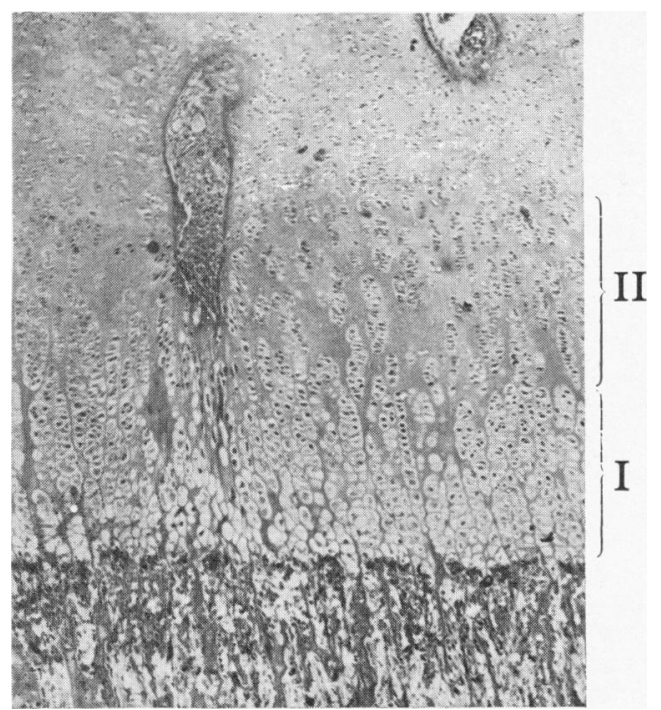

FIG. 2.-The normal costochondral junction at term. Note that the junctional line is straight. The section is close to a large central vessel. The distinction between the first $(I)$ and second (II) zones of the cartilage can also be seen. This is the same rib as is shown in Fig. $1 D$ but at a magnification of $\times 40$.
FIG. 4 (see opposite).-Rib ends showing irregular lines and a bizarre pattern.

(A) From a stillborn child at 34 weeks. The mother had hypertension. This rib shows irregular compound cartilage and an indefinite junctional line behind a partly mineralized band (see arrow). ( $\times$ 88.)

(B) $A$ higher power view of part of the rib end shown in Fig. 3, showing irregular masses of partly mineralized matrix. ( $\times$ 100.)

(C) From a child stillborn at 23 weeks. The mother had eclampsia and the child was born following an antepartum haemorrhage due to placenta praevia. The costochondral junction was irregular and the whole picture bizarre. The rib suggests that the placenta praevia was a minor factor in this child's death. ( $\times 100$.

(D) This stillborn child was born at 42 weeks, weight $2090 \mathrm{~g}$. The rib end shows irregular bridging and banding with irregular mineralization. There has obviously been some considerably greater and more long-standing upset in the child's metabolism than simple terminal placental insufficiency. $(\times$ 100.

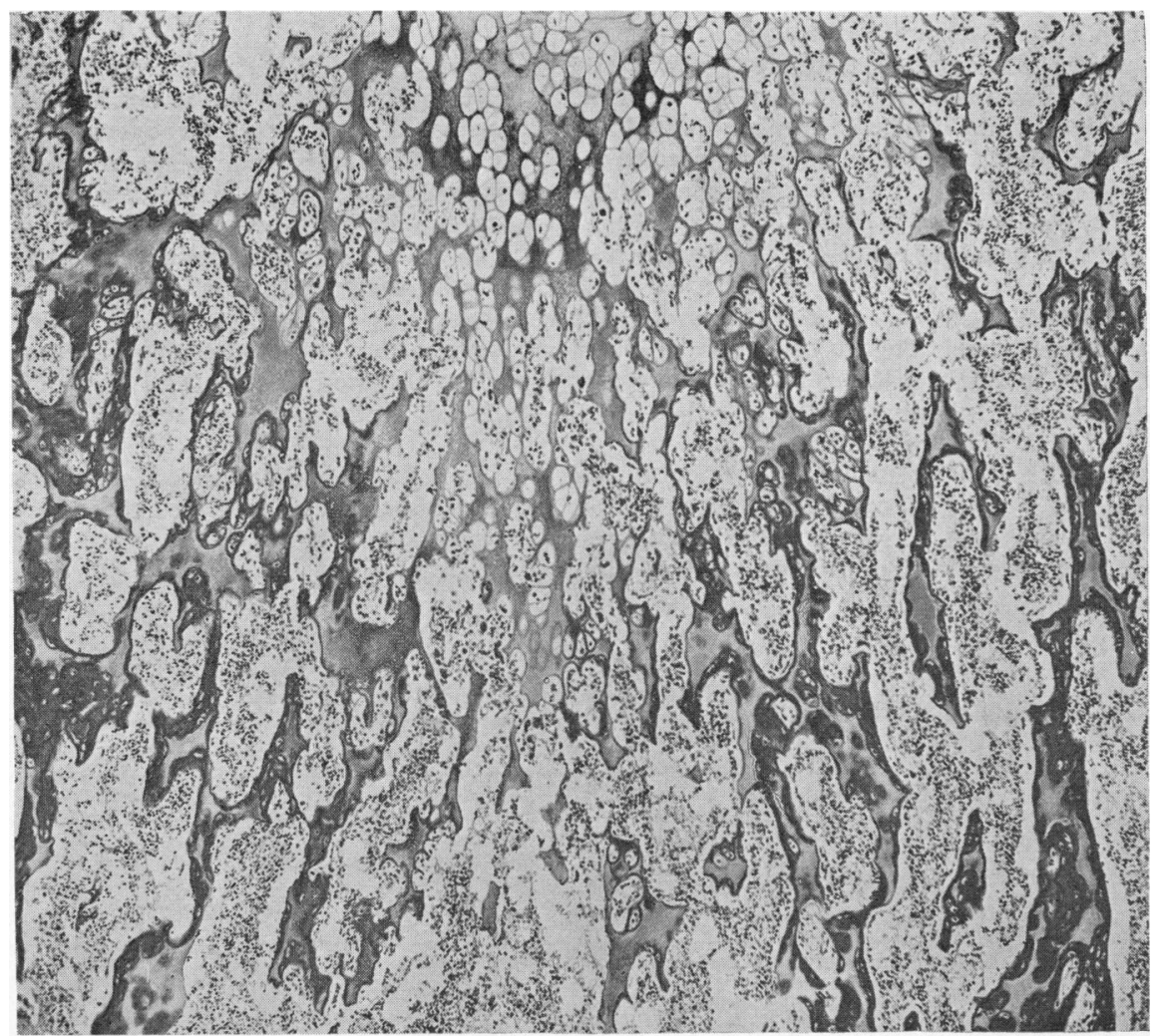

FIG. 3.-Rib from a stillborn child at 40-41 weeks' maturity. The child had a deformity of the heart and the mother had oedema and albuminuria with no hypertension. This rib end shows a bizarre picture. Compare with Fig. 2, normal. $(\times 15$. 

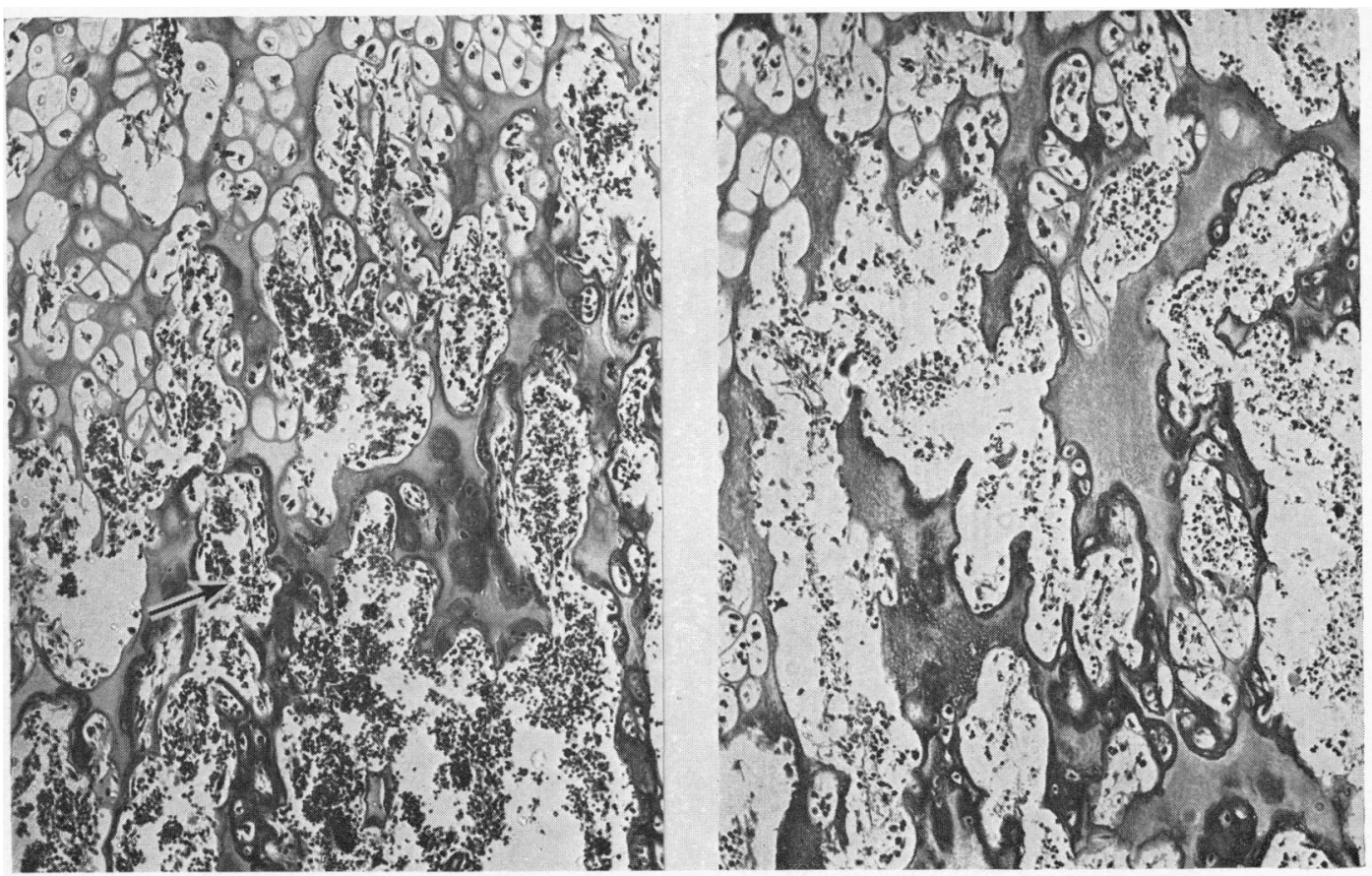

A

B
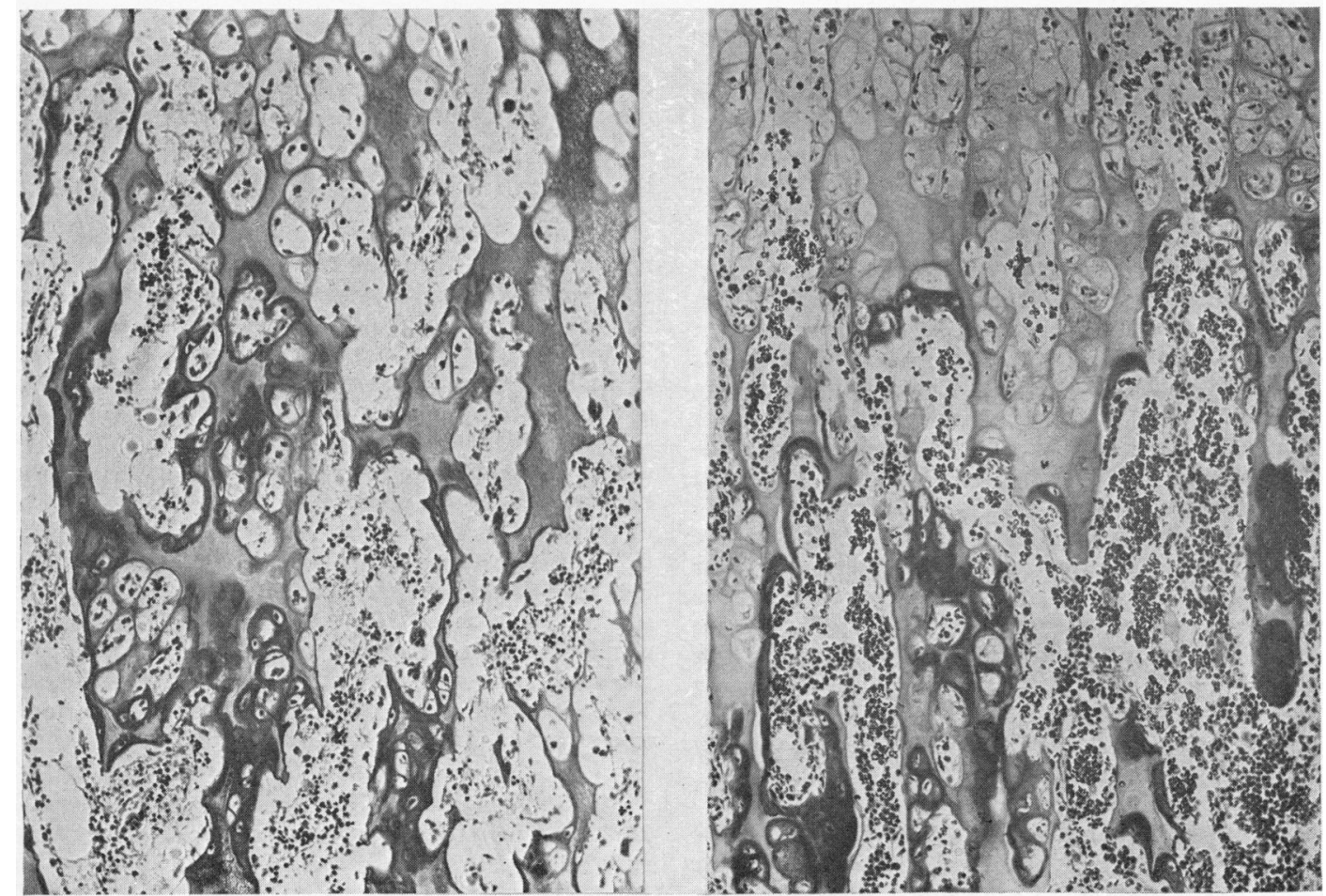

C

FIG. 4.

$D$ 


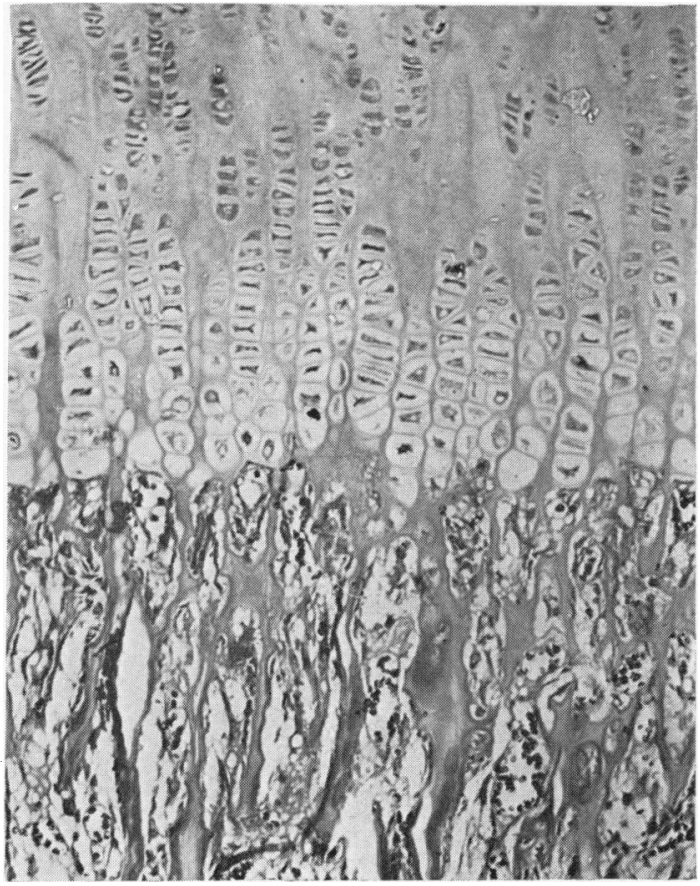

FIG. 5.-Costochondral junction of a stillborn child born at $\mathbf{4 0}$ weeks' gestation. The child died during labour with massive inhalation of liquor and cerebral oedema. Compare this rib with Fig. $1 C$ or D. Note the simplicity of the cartilage columns: the cells are in single file and there is an abnormal amount of matrix. There is also a line of matrix between the cartilage cells and the trabeculi. This rib shows a diminution in growth rate with no complete cessation of growth. $(\times 100$.

Most of the cartilage consists of the general 'resting' tissue in which there is a large amount of matrix within which single or paired cartilage cells appear to be at random. These are what Dodds terms the reserve cells (Dodds, 1930). Near the costochondral junction the cartilage cells divide, forming double and single rows of cells, and these columns of cells become orientated towards the bone: this we term zone II (Fig. 2). Between zone II and the marrow cavity, the cartilage cells are arranged in columns with the cells, as seen in routine paraffin sections, having a larger and larger perinuclear clear area until the final cell appears to be bursting into the bone trabeculae: this we term zone I (Fig. 2). These zones are much more distinct in the older ribs and in ribs in which there is an arrest of growth, than in very young and normal ribs (compare Fig. 1 with Fig. 5). The depth of these zones (I and II) was measured directly with an eyepiece micrometer.

Form of cartilage columns. The cartilage columns of zone I were divided into two groups. (a) Simple columns in which the cells form a single row (like peas in a pod) with a thin, almost straight thread of matrix running between the rows (Fig. 5). (b) Compound in which the cartilage cells are packed irregularly together (like seeds in a pomegranate). Often the rows are just double or treble with bands of matrix between the double rows (compound regular, Fig. 1) or with no regular matrix (compound irregular, Fig. 4).

Number of cells in column. Where simple columns exist, it is simple to count the number of cells in the column from the bone to the junction between zones I and II. When the cells are in compound columns, whether regular or irregular, the number of cells can be counted by observing the number of cells cut by an eyepiece hair-line in zone I.

Bridging. Where the columns of cartilage cells impinge on the bone, the thin strands of matrix between the columns normally continue within the marrow for a short and variable distance (Fig. 1). In the normal bone, there is a gradual diminution in these trabeculae. When the cartilage cells are in simple columns, there are trabeculae between each cell line.

Under abnormal conditions, the absorption of the trabeculae in the marrow appears to overtake their production so that they are eliminated up to the cartilage cell face, and the residual trabeculae then 'bridge' a number of cartilage columns (Fig. 4 and 6). Bridging was reported positive if bridges occurred covering two or more primary matrix strands in more than two areas across the rib (Tables III, IV, and V).

Banding. When the cartilage cells fail to burst into the marrow cavity, a band of matrix can be seen between the terminal cartilage cells and the bone cavity (Fig. 6 and 8). This matrix is of irregular thickness but obviously forms a discontinuous plate over the end of the cartilage.

When the bone begins growing again, these plates remain as transverse bands of matrix, calcified matrix, and part-formed bone within the end of the bone, and run roughly parallel to the costochondral junctional line. There are, thus, two types of banding: one, as it were, in situ between the bone and the cartilage, and the other, as a series of tide-marks within the bone shaft (Fig. 7).

We restrict the term 'banding' to the first, free type, only. Banding was recorded as positive if one or more bands could be seen extending more than a half of the distance across the rib end (Tables IV and V).

There are a number of other features that are taken into consideration when a rib end is assessed, such as the size of the cartilage cells, the distance of the trabecular capillaries from the ends of the trabeculae, and the amount of connective tissue around the trabeculae. These seemed to be less amenable to reproducible assessment and are not tabulated here.

Method of survey. Ribs from a continuous series of 2000 necropsies were taken, and all of the rib ends were surveyed and measured by one of us (P.K.K.), with no knowledge of the child's age or maturity at death. The ribs from the Perinatal Mortality Survey were examined 


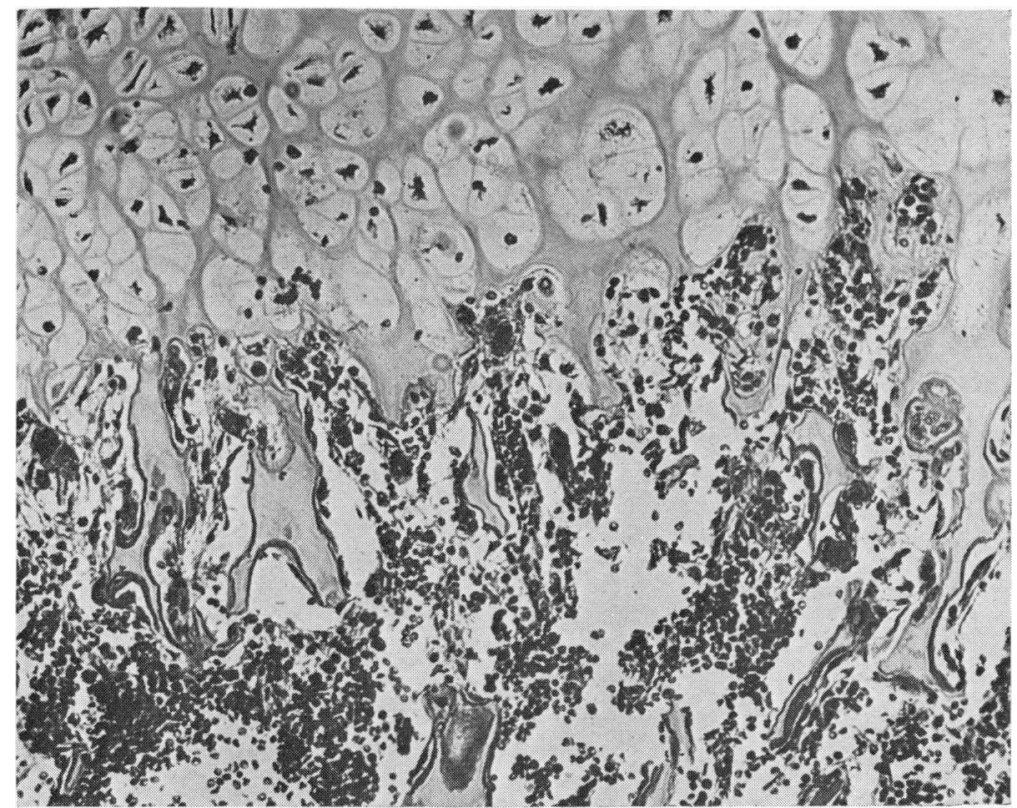

FIG. 6.-Rib from a child who died within 36 hours of birth, superficially from birth trauma following a breech extraction. The junctional line is irregular, there are zones of matrix between the ballooned cartilage cells and the trabeculae. The marrow cavity has encroached on and almost reaches the cartilage. The marrow trabeculae themselves are short and abnormally irregular, also indicating growth arrest. ( $\times 130$.

in a similar way. The findings and conclusions were recorded on a research protocol. All the ribs had previously been examined and a written report made by one of us (J.L.E.). These data and the clinical details of the case were then collated and studied. It was found that there was some disagreement between the findings and conclusions of the first and second observer in 1 in 20 of the ribs. These ribs were then surveyed again by both workers.

Only the cases in which the child's gestational age was known were retained. From the Sheffield series of 2000 ribs, 1500 were from perinatal deaths, and of these only $684 \mathrm{had}$ an adequate history for further analysis. Of the 500 ribs available from the Perinatal Mortality Survey, 380 were adequate. Thus, the total number of ribs analysed was 1064 .

The cases fell into three fairly distinct groups, based on the criteria shown in Table I. The findings in each group (normal, cessation, and bizarre), were analysed (Tables II, III, IV, and V) in relation to the gestational age of the children at birth, and the proportion of children showing the different types of lesion who died before, during, or after birth.

\section{Results}

Normal (Table III). So little of the necropsy material of the perinatal period can legitimately be called normal that the elucidation of the normal pattern of the rib end at different months of gestation is only possible from the assessment of a very large number of cases, and from the extremely rare truly accidental death.

When we first began looking at the costochondral junction from perinatal deaths, the first impression gained was not unlike that of Park who once remarked that they all showed the changes of rickets. It was only after looking at tissues from some infants that had died quickly as a result of sudden accidents, and finding that their costochondral junctions were remarkably similar to the appearances in older children also dying of accidents that criteria for normality could be derived.

Of the 1064 ribs surveyed, 332 came within our classification of normal. Within these cases, there appeared to be a greater proportion of children with normal rib ends in the children of low gestation than those dying around term. In the children of gestation 19 to 30 weeks, $41 \%$ were normal, of 30-33 weeks $42 \%$ were normal, of $33-38$ weeks $27 \%$ were normal, and of 38-41 weeks $29 \%$ were normal, and in the relatively small group of cases dying over 41 weeks' gestation, only $8 \%$ were normal.

From the viewpoint of the form of the costochondral junction line, the latter appeared to become progressively more distinct in the children of higher 


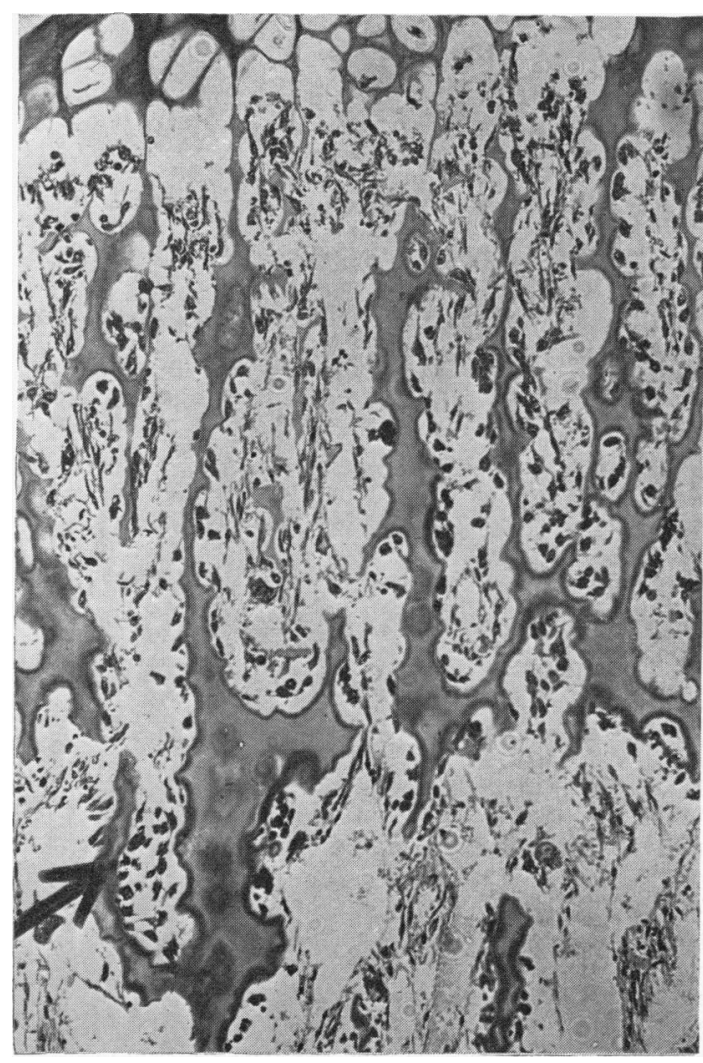

FIG. 7.-Rib from a stillborn child at 31 weeks. The mother sustained a severe road accident 2 weeks before she went into labour. The rib end in this child shows $a$ band across the trabeculae approximately $4 \mathrm{~mm}$. from the cartilage (see arrow). This band was probably related to the mother's accident; and represents a phase of growth cessation, either related to a concealed placental haemorrhage or to the effect of shock on the mother's blood pressure. $(\times 127$.

gestation. In about one-third of the children between 19 and 30 weeks' gestation, the line was indistinct, but this did not apply to the ribs over 34 weeks' gestation. The form of the costochondral junction line was only straight in one-third of the children born beyond 41 weeks.

Regarding the cartilage columns: these became progressively more simple and less compact with increased gestation. The numbers of cells in the cartilage columns also appeared to be greatest in the youngest age-group. In all the 59 children between 19 and 30 weeks, the cartilage columns had over 15 cells. The total depth of the cartilage also appeared to be greater in the very young babies and to get progressively less. There was an occasional rib that was thought to be normal, though it had some

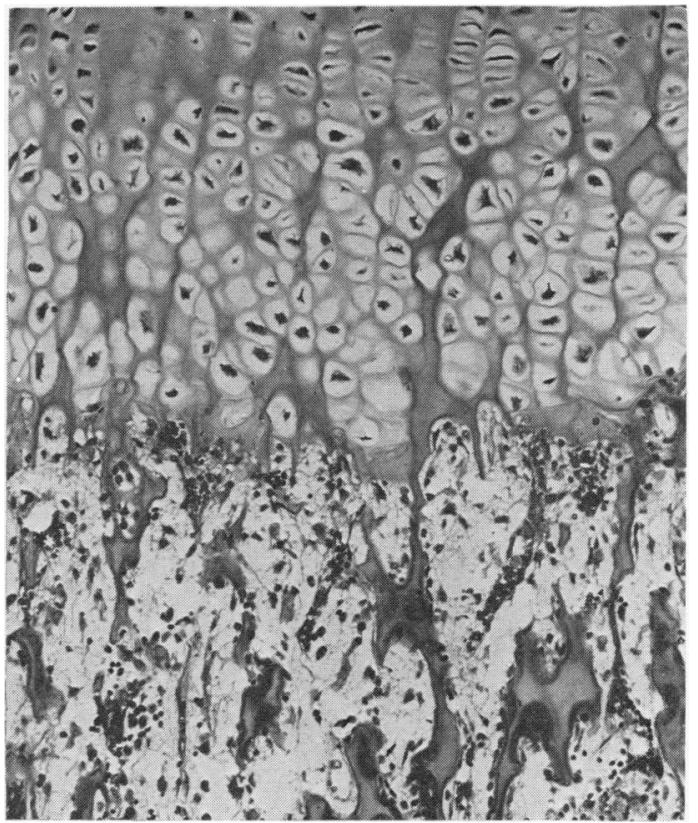

FIG. 8.-Rib from a child dying at the age of 5 days with an imperforate anus, having been severely ill from the moment of birth. Note the band of matrix separating the cartilage cells from the trabeculae. This probably represents a complete cessation of growth for at least 5 days after birth. Compare the concentration and appearance of the active cartilage cells in this case with those in Fig. 5. This present child had probably been growing normally almost up to the time of birth. $(\times 110$.

bridging. It must be remembered that these ribs were categorized on several criteria, and if only one criteria appeared abnormal, the rib was not necessarily abnormal. This implies that our criteria for allowing a rib as normal may have been too lax and we may have included a number of abnormal ribs among those classified as normal. However, if we had been more strict in our criteria, it would only have been likely to produce a significant change in the number of cases in the children of gestation 19-30 weeks.

Photographs of what are probably normal ribs from children of different gestational ages are presented in Fig. 1 where most of the features just described are obvious.

In general, the characteristics of a normal costochondral junction at any age over 30 weeks' gestation are: the distinct junctional line which, while it is often curved, is regular; the cartilage cells in distinct columns; the total thickness of the active cartilage between 0.08 and $0.12 \mathrm{~mm}$. While there may be an occasional bridge, these are uncommon 
TABLE II

Number and Proportion of Ribs Showing Normal Appearance, Growth Arrest, and Bizarre Appearance in Children Grouped According to Gestational Age

\begin{tabular}{|c|c|c|c|c|c|c|c|c|c|c|c|c|c|}
\hline \multirow{3}{*}{$\begin{array}{c}\text { Gestation } \\
(w k .)\end{array}$} & \multirow{3}{*}{ Rib End } & \multicolumn{8}{|c|}{ Sheffield Survey } & \multirow{2}{*}{\multicolumn{2}{|c|}{$\begin{array}{c}\begin{array}{c}\text { Perinatal } \\
\text { Mortality } \\
\text { Survey }\end{array} \\
\begin{array}{c}\text { Stillborn to } \\
\mathbf{7} \text { dy. }\end{array}\end{array}$}} & \multicolumn{2}{|c|}{ Sum Total } \\
\hline & & \multicolumn{2}{|c|}{$\begin{array}{l}\text { Stillborn to } \\
5 \mathrm{hr} \text {. }\end{array}$} & \multicolumn{2}{|c|}{$\begin{array}{l}5 \mathrm{hr} .10 \mathrm{~min} . \\
\text { to } 48 \mathrm{hr} \text {. }\end{array}$} & \multicolumn{2}{|c|}{$\begin{array}{l}48 \mathrm{hr} .10 \mathrm{~min} . \\
\text { to } 7 \mathrm{dy} \text {. }\end{array}$} & \multicolumn{2}{|c|}{ Total } & & & \multirow[t]{2}{*}{ No. } & \multirow[t]{2}{*}{$\%$} \\
\hline & & No. & $\%$ & No. & $\%$ & No. & $\%$ & No. & $\%$ & No. & $\%$ & & \\
\hline $19-30 \cdot 5$ & $\begin{array}{c}\text { Normal } \\
\text { Growth arrest } \\
\text { Bizarre }\end{array}$ & $\begin{array}{l}32 \\
38 \\
12\end{array}$ & $\begin{array}{l}39 \\
46 \\
15\end{array}$ & $\begin{array}{r}27 \\
21 \\
4\end{array}$ & $\begin{array}{r}52 \\
40 \\
8\end{array}$ & $\begin{array}{l}6 \\
0 \\
3\end{array}$ & $\left.\frac{67}{33}\right\}$ & $\begin{array}{l}65 \\
78\end{array}$ & $\begin{array}{l}45 \\
55\end{array}$ & $\begin{array}{r}19 \\
35 \\
8\end{array}$ & $\left.\begin{array}{l}31 \\
56 \\
13\end{array}\right\}$ & $\begin{array}{r}84 \\
121\end{array}$ & $\begin{array}{l}41 \\
59\end{array}$ \\
\hline $30 \cdot 6-33 \cdot 5$ & $\begin{array}{c}\text { Normal } \\
\text { Growth arrest } \\
\text { Bizarre }\end{array}$ & $\begin{array}{l}24 \\
17 \\
17\end{array}$ & $\begin{array}{l}41 \\
29 \\
29\end{array}$ & $\begin{array}{r}12 \\
12 \\
9\end{array}$ & $\begin{array}{l}36 \\
36 \\
27\end{array}$ & $\begin{array}{l}3 \\
0 \\
0\end{array}$ & $\stackrel{100}{-}\}$ & $\begin{array}{l}39 \\
55\end{array}$ & $\begin{array}{l}41 \\
59\end{array}$ & $\begin{array}{l}23 \\
15 \\
15\end{array}$ & $\left.\begin{array}{l}43 \\
28 \\
28\end{array}\right\}$ & $\begin{array}{l}64 \\
85\end{array}$ & $\begin{array}{l}42 \\
58\end{array}$ \\
\hline $33 \cdot 6-38 \cdot 0$ & $\begin{array}{l}\text { Normal } \\
\text { Growth arrest } \\
\text { Bizarre }\end{array}$ & $\begin{array}{l}25 \\
47 \\
26\end{array}$ & $\begin{array}{l}26 \\
48 \\
27\end{array}$ & $\begin{array}{r}12 \\
19 \\
9\end{array}$ & $\begin{array}{l}30 \\
48 \\
22\end{array}$ & $\begin{array}{r}16 \\
17 \\
9\end{array}$ & $\left.\begin{array}{l}38 \\
41 \\
21\end{array}\right\}$ & $\begin{array}{r}53 \\
127\end{array}$ & $\begin{array}{l}29 \\
71\end{array}$ & $\begin{array}{l}26 \\
54 \\
32\end{array}$ & $\left.\begin{array}{l}23 \\
48 \\
29\end{array}\right\}$ & $\begin{array}{r}79 \\
213\end{array}$ & $\begin{array}{l}27 \\
72\end{array}$ \\
\hline $38 \cdot 1-41 \cdot 5$ & $\begin{array}{c}\text { Normal } \\
\text { Growth arrest } \\
\text { Bizarre }\end{array}$ & $\begin{array}{l}39 \\
88 \\
16\end{array}$ & $\begin{array}{l}27 \\
62 \\
11\end{array}$ & $\begin{array}{r}12 \\
22 \\
5\end{array}$ & $\begin{array}{l}31 \\
56 \\
13\end{array}$ & $\begin{array}{r}20 \\
25 \\
8\end{array}$ & $\left.\begin{array}{l}38 \\
47 \\
15\end{array}\right\}$ & $\begin{array}{r}71 \\
164\end{array}$ & $\begin{array}{l}30 \\
70\end{array}$ & $\begin{array}{l}31 \\
73 \\
17\end{array}$ & $\left.\begin{array}{l}26 \\
60 \\
14\end{array}\right\}$ & $\begin{array}{l}102 \\
254\end{array}$ & $\begin{array}{l}29 \\
71\end{array}$ \\
\hline $41 \cdot 6$ and over & $\begin{array}{c}\text { Normal } \\
\text { Growth arrest } \\
\text { Bizarre }\end{array}$ & $\begin{array}{l}3 \\
7 \\
5 \\
\end{array}$ & $\begin{array}{l}20 \\
33 \\
47 \\
\end{array}$ & $\begin{array}{l}1 \\
7 \\
2 \\
\end{array}$ & $\begin{array}{l}10 \\
70 \\
20 \\
\end{array}$ & $\begin{array}{l}0 \\
6 \\
1 \\
\end{array}$ & $\left.\begin{array}{l}\overline{86} \\
14\end{array}\right\}$ & $\begin{array}{r}4 \\
28\end{array}$ & $\begin{array}{l}12 \\
88\end{array}$ & $\begin{array}{r}1 \\
30 \\
1 \\
\end{array}$ & $\left.\begin{array}{r}3 \\
94 \\
3\end{array}\right\}$ & $\begin{array}{r}5 \\
59\end{array}$ & $\begin{array}{r}8 \\
92\end{array}$ \\
\hline All cases & $\begin{array}{l}\text { Normal } \\
\text { Growth arrest } \\
\text { Bizarre }\end{array}$ & \multicolumn{2}{|c|}{$\begin{array}{r}123 \\
197 \\
76\end{array}$} & \multicolumn{2}{|c|}{$\begin{array}{l}64 \\
81 \\
29\end{array}$} & \multicolumn{2}{|c|}{$\left.\begin{array}{l}45 \\
48 \\
21\end{array}\right\}$} & \multicolumn{2}{|c|}{232} & \multicolumn{2}{|c|}{$\left.\begin{array}{r}100 \\
207 \\
73\end{array}\right\}$} & \multicolumn{2}{|c|}{$\begin{array}{l}332 \\
732\end{array}$} \\
\hline Totals & & \multicolumn{2}{|c|}{396} & \multicolumn{2}{|c|}{174} & \multicolumn{2}{|c|}{114} & \multicolumn{2}{|c|}{684} & \multicolumn{2}{|c|}{380} & \multicolumn{2}{|c|}{1064} \\
\hline
\end{tabular}

TABLE III

Measurements and Findings of 'Normal' Costochondral Junction in 187 Children of Varying Gestational Age, Stillborn, or Dying within 48 Hours of Delivery

\begin{tabular}{|c|c|c|c|c|c|c|c|c|c|c|c|c|c|c|c|}
\hline \multirow{3}{*}{$\begin{array}{c}\text { Gestational } \\
\text { Age } \\
\text { (wk.) }\end{array}$} & \multirow{3}{*}{$\begin{array}{l}\text { No. } \\
\text { of } \\
\text { Cases }\end{array}$} & \multicolumn{4}{|c|}{ Form of Junction Lines } & \multirow{3}{*}{$\begin{array}{c}\text { Cartilage } \\
\text { Columns } \\
\text { Simple }\end{array}$} & \multirow{2}{*}{\multicolumn{3}{|c|}{$\begin{array}{l}\text { No. of Cells in } \\
\text { Cartilage Columns }\end{array}$}} & \multicolumn{4}{|c|}{$\begin{array}{l}\text { Depth of Active } \\
\text { Cartilage (mm.) }\end{array}$} & \multirow{2}{*}{\multicolumn{2}{|c|}{ 'Bridging' }} \\
\hline & & \multirow{2}{*}{ 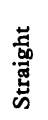 } & \multirow{2}{*}{ 总 } & \multirow{2}{*}{ 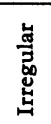 } & \multirow{2}{*}{ 莺 } & & & & & Zon & e I & Zor & II & & \\
\hline & & & & & & & $\begin{array}{l}\text { Up to } \\
10\end{array}$ & $11-14$ & $\begin{array}{c}\text { Over } \\
15\end{array}$ & $\begin{array}{l}\text { Up to } \\
0 \cdot 04\end{array}$ & $\begin{array}{l}\text { Over } \\
0 \cdot 04\end{array}$ & $\begin{array}{l}\text { Up to } \\
0 \cdot 08\end{array}$ & $\begin{array}{l}\text { Over } \\
0.08\end{array}$ & - ve & tre \\
\hline $\begin{array}{c}19-30 \cdot 5 \\
30 \cdot 6-33 \cdot 5 \\
33 \cdot 6-38 \\
38 \cdot 1-41 \cdot 5 \\
41 \cdot 6 \text { and over }\end{array}$ & $\begin{array}{r}59 \\
36 \\
37 \\
51 \\
4\end{array}$ & $\begin{array}{l}12 \\
23 \\
18 \\
12 \\
33\end{array}$ & $\begin{array}{l}51 \\
71 \\
82 \\
68 \\
67\end{array}$ & $\frac{5}{19}$ & $\begin{array}{r}32 \\
6 \\
\frac{1}{-}\end{array}$ & $\begin{array}{l}23 \\
42 \\
56 \\
63 \\
67\end{array}$ & $\begin{array}{r}0 \\
0 \\
14 \\
2 \\
0\end{array}$ & $\begin{array}{r}0 \\
4 \\
6 \\
3 \\
16\end{array}$ & $\begin{array}{r}100 \\
96 \\
80 \\
95 \\
84\end{array}$ & $\begin{array}{r}57 \\
72 \\
79 \\
75 \\
100\end{array}$ & $\begin{array}{r}43 \\
28 \\
21 \\
25 \\
0\end{array}$ & $\begin{array}{r}12 \\
8 \\
8 \\
25 \\
16\end{array}$ & $\begin{array}{l}88 \\
92 \\
92 \\
75 \\
84\end{array}$ & $\begin{array}{r}80 \\
98 \\
100 \\
98 \\
100\end{array}$ & $\begin{array}{r}20 \\
2 \\
0 \\
2 \\
0\end{array}$ \\
\hline
\end{tabular}

Note: Figures are presented as percentage incidence of category studied.

TABLE IV

Measurements and Findings of Ribs Showing Growth Cessation in 278 Children of Varying Gestational Age, Stillborn, or Dying Within 48 Hours of Delivery

\begin{tabular}{|c|c|c|c|c|c|c|c|c|c|c|c|c|c|c|c|c|c|}
\hline \multirow{3}{*}{$\begin{array}{c}\text { Gestational } \\
\text { Age } \\
\text { (wk.) }\end{array}$} & \multirow{3}{*}{$\begin{array}{c}\text { No. } \\
\text { of } \\
\text { Cases }\end{array}$} & \multicolumn{4}{|c|}{ Lines } & \multirow{3}{*}{$\begin{array}{l}\text { Simple } \\
\text { Cartilage } \\
\text { Columns }\end{array}$} & \multirow{2}{*}{\multicolumn{3}{|c|}{$\begin{array}{l}\text { No. of Cells in } \\
\text { Cartilage Columns }\end{array}$}} & \multicolumn{4}{|c|}{$\begin{array}{l}\text { Depth of Cartilage Columns } \\
\text { in Costochondral Junction } \\
\text { (mm.) }\end{array}$} & \multirow{2}{*}{\multicolumn{2}{|c|}{ Bridging }} & \multirow{2}{*}{\multicolumn{2}{|c|}{ Banding }} \\
\hline & & \multirow{2}{*}{ 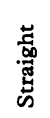 } & \multirow{2}{*}{ : } & \multirow{2}{*}{ 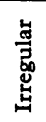 } & \multirow{2}{*}{ 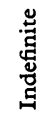 } & & & & & Zor & $\frac{(\mathrm{m}}{\mathrm{e} I}$ & Zon & II & & & & \\
\hline & & & & & & & $\begin{array}{c}\text { Up to } \\
10\end{array}$ & $11-14$ & $\begin{array}{c}\text { Over } \\
15\end{array}$ & $\begin{array}{l}\text { Up to } \\
0.04\end{array}$ & $\begin{array}{l}\text { Over } \\
0.04\end{array}$ & $\begin{array}{l}\text { Up to } \\
0.08\end{array}$ & $\begin{array}{l}\text { Over } \\
0.08\end{array}$ & - ve & + ve & -ve & +ve \\
\hline $\begin{array}{c}19-30 \cdot 5 \\
30 \cdot 6-33 \cdot 5 \\
33 \cdot 6-38 \cdot 0 \\
38 \cdot 1-41 \cdot 5 \\
\text { Over } 41 \cdot 6\end{array}$ & $\begin{array}{r}59 \\
29 \\
66 \\
110 \\
14\end{array}$ & $\begin{array}{r}4 \\
7 \\
3 \\
17\end{array}$ & $\begin{array}{l}54 \\
63 \\
55 \\
51 \\
40\end{array}$ & $\begin{array}{l}31 \\
28 \\
33 \\
39 \\
41\end{array}$ & $\begin{array}{r}11 \\
9 \\
5 \\
7 \\
2\end{array}$ & $\begin{array}{l}35 \\
46 \\
40 \\
49 \\
39\end{array}$ & $\begin{array}{l}-6 \\
3 \\
2 \\
\end{array}$ & $\begin{array}{l}\text { 二 } \\
2 \\
6 \\
2\end{array}$ & $\begin{array}{r}100 \\
94 \\
95 \\
92 \\
98\end{array}$ & $\begin{array}{l}63 \\
88 \\
86 \\
85 \\
71\end{array}$ & $\begin{array}{l}37 \\
12 \\
14 \\
15 \\
29\end{array}$ & $\begin{array}{r}7 \\
15 \\
12 \\
16 \\
21\end{array}$ & $\begin{array}{l}93 \\
85 \\
88 \\
84 \\
79\end{array}$ & $\begin{array}{l}45 \\
53 \\
35 \\
38 \\
31\end{array}$ & $\begin{array}{l}55 \\
47 \\
65 \\
62 \\
69\end{array}$ & $\begin{array}{r}21 \\
22 \\
4 \\
1 \\
9\end{array}$ & $\begin{array}{l}79 \\
78 \\
96 \\
99 \\
91\end{array}$ \\
\hline
\end{tabular}

Note: Figures are presented as percentage incidence of category studied. 
TABLE V

Measurements and Findings of Ribs Having a Bizarre Costochondral Junction in 105 Children of Varying Gestational Age, Stillborn, or Dying Within 48 Hours of Delivery

\begin{tabular}{|c|c|c|c|c|c|c|c|c|c|c|c|c|c|c|c|c|c|}
\hline \multirow{4}{*}{$\begin{array}{l}\text { Gestational } \\
\text { Age } \\
\text { (wk.) }\end{array}$} & \multirow{4}{*}{$\begin{array}{c}\text { No. } \\
\text { of } \\
\text { Cases }\end{array}$} & \multicolumn{4}{|c|}{ Lines } & \multirow{4}{*}{$\begin{array}{l}\text { Simple } \\
\text { Cartilage } \\
\text { Columns }\end{array}$} & \multirow{3}{*}{\multicolumn{3}{|c|}{$\begin{array}{l}\text { No. of Cells in } \\
\text { Cartilage Columns }\end{array}$}} & \multirow{2}{*}{\multicolumn{4}{|c|}{$\begin{array}{l}\text { Depth of Cartilage Columns } \\
\text { in Costochondral Junction } \\
\text { (mm. }\end{array}$}} & \multirow{3}{*}{\multicolumn{2}{|c|}{ Bridging }} & \multirow{3}{*}{\multicolumn{2}{|c|}{ Banding }} \\
\hline & & \multirow{3}{*}{ 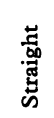 } & \multirow{3}{*}{ 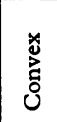 } & \multirow{3}{*}{ 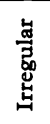 } & \multirow{3}{*}{ 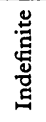 } & & & & & & & & & & & & \\
\hline & & & & & & & & & & Zor & I & Zon & e II & & & & \\
\hline & & & & & & & $\begin{array}{c}\text { Up to } \\
10\end{array}$ & $11-14$ & $\begin{array}{c}\text { Over } \\
15\end{array}$ & $\begin{array}{l}\text { Up to } \\
0.04\end{array}$ & $\begin{array}{l}\text { Over } \\
0.04\end{array}$ & $\begin{array}{c}\text { Up to } \\
0.08\end{array}$ & $\begin{array}{l}\text { Over } \\
0.08\end{array}$ & - ve & + ve & -ve & + ve \\
\hline $\begin{array}{c}19-30 \cdot 5 \\
30 \cdot 6-33 \cdot 5 \\
33 \cdot 6-38 \cdot 0 \\
38 \cdot 1-41 \cdot 5 \\
\text { Over } 41 \cdot 6\end{array}$ & $\begin{array}{r}16 \\
26 \\
35 \\
21 \\
7\end{array}$ & $\frac{-}{2}$ & $\begin{array}{r}4 \\
17 \\
6 \\
9 \\
30\end{array}$ & $\begin{array}{l}75 \\
66 \\
79 \\
82 \\
25\end{array}$ & $\begin{array}{r}21 \\
17 \\
13 \\
9 \\
45\end{array}$ & $\begin{array}{l}29 \\
11 \\
37 \\
42 \\
20\end{array}$ & $\bar{z}$ & $\begin{array}{r}- \\
3 \\
2 \\
6 \\
10\end{array}$ & $\begin{array}{r}100 \\
97 \\
88 \\
81 \\
90\end{array}$ & $\begin{array}{l}42 \\
80 \\
53 \\
63 \\
90\end{array}$ & $\begin{array}{l}58 \\
20 \\
47 \\
37 \\
10\end{array}$ & $\begin{array}{r}13 \\
3 \\
21 \\
19 \\
20\end{array}$ & $\begin{array}{l}87 \\
97 \\
79 \\
81 \\
80\end{array}$ & $\begin{array}{l}92 \\
85 \\
92 \\
44 \\
65\end{array}$ & $\begin{array}{r}8 \\
15 \\
8 \\
56 \\
35\end{array}$ & $\begin{array}{l}67 \\
83 \\
68 \\
55 \\
65\end{array}$ & $\begin{array}{l}33 \\
17 \\
32 \\
45 \\
35\end{array}$ \\
\hline
\end{tabular}

Note: Figures are presented as percentage incidence of category studied.

and there is no cross-banding. This, in effect, is the description of a normal rib end as described by many previous workers (Park, 1964).

Growth cessation. Evidence of a diminution in growth rate was seen in 278 ribs. This involved $56 \%$ of children dying at $19-30$ weeks, $28 \%$ at $30-33$ weeks, $48 \%$ at $34-38$ weeks, $60 \%$ at $38-41$ weeks, and $94 \%$ of those over 41 weeks.

Details of the measurements in these cases are shown in Table IV. It is obvious that the junctional line is less regular than in the normal subjects. In about $7 \%$ the junctional line was indistinct. This is frequently the case when there has been irregular growth and where a period of growth follows the production of a band of growth cessation (see Fig. 4A and 7). A little less than half the cartilage cells were in single columns, but the actual number of cells in these columns was not greatly reduced, as compared with the normal one. The depth of the first zone of cells, however, was considerably reduced, while that of the second remained as in the normal subjects. The reduction in depth of the first zone reflects a diminished 'plumping up' of the cells.

Both bridging and banding are greatly increased over-all: $60 \%$ of the ribs show multiple bridging and up to $90 \%$ multiple bands-banding being the essential stigmata of growth retardation. Within the growth retardation group, there was bound to be very great variation, as the amount of disturbance likely to be found is, of necessity, related to the duration and severity of the retardation in growth. Examples of a recent (i.e. terminal), a single postcessation, and multiple post-cessation in growth are illustrated in Fig. 4, 6, 7, and 8.

With growth retardation, there are usually two other changes not listed in Table I: these are, an increased mineralization of the bone and matrix near the cartilage, and a diminution in cellularity of the connective tissue between the capillaries in the trabeculae and the osteoid or bone spicules.

Bizarre. The incidence of the bizarre form is less than that of simple growth retardation, there being 105 cases among the 1064 studied. The highest incidence of the deformity lies in the children of gestation between 30 and 38 weeks. The characteristics of the bizarre picture are shown in Fig. 4 and the measurements in Table V. The junctional line is either very irregular or quite indistinct, only a few of the cartilage columns being in rows of single cells. The numbers of cells in the cartilage column are, if anything, increased, but in this group the irregularity of the compound columns makes the junction between zones I and II of the active cartilage cells often quite indistinct.

The total depth of the active cartilage zone is often increased beyond $0.12 \mathrm{~mm}$. Bridging and banding are not so obvious as in growth retardation, but are almost always present. The most characteristic finding is the presence of irregular masses of matrix lying among the disorganized mixture of cartilage cells and trabeculae. This picture is not that of rickets, as there is no great increase in the amount of calcified matrix. If we revert to our simile of rockets, the impression gained is that the cartilage cells are maturing (swelling and bursting) before they have become organized longitudinally, so that the discharges are given off in all directions.

\section{Discussion}

The approach to the structure of the rib, and the interpretation of the normal and abnormal appearances that we have used, differ in no way from that of a large number of workers (Dodds, 1930; Follis, 1958; Park, 1954). We have only attempted to apply established histopathology as a 'retrospectroscope' within the field of perinatal death. 
There seems little doubt but that the costochondral growth during the latter half of intrauterine life follows the same pattern as it does in postnatal life. The 4th, 5th, and 6th ribs have been selected for study as they form the sites at which disturbances in growth are most obvious and are identifiable earliest -this was recognized during the work on scurvy and rickets (Follis, 1958; Wersch, 1954). Reasons why the costochondral junction has not been prominent in clinical work are due largely to the difficulty in obtaining good $x$-ray pictures in the living child.

A very large amount of work has been done on the effects of undernourishment and of infections (Jackson, 1924; Follis, 1958; Pratt and McCance, 1960) on the costochondral junction in experimental animals. It has been shown that changes can be seen in the rib of an experimental animal within a very short time of the onset of a stress and can be relieved in a similar brief time (Silberberg and Silberberg, 1940). The earliest changes lie in the cellular structure of the sinuses near the final trabeculae and the relation of the blood vessels to the matrix and to the glycogen content of the cartilage cells. These changes are obvious in a very large number of ribs examined in perinatal death, but since these 'acute' changes can be related to terminal illness, we have deliberately excluded them from this particular survey and concentrated on the lesions that must have occurred while the child was growing in the uterus.

The abnormalities seen in the rib ends fell easily into the two groups we have described (i.e. growth arrest and bizarre growth). After we had been using this classification for several years, we were intrigued to find that Cohen (1948), who surveyed the costochondral junction of infants and children coming to necropsy at the Children and Infants Hospital in Boston, divided his abnormal ribs into two separate, non-specific changes: (1) growth arrest, with thinning of what he terms the 'cytomorphic' zone of the cartilage (what in our classification combines zones I and II), and (2) non-specific disturbance in growth, in which there is a thickening of the active cartilage and which appears to be analogous to what we term bizarre growth.

The term 'cessation' of growth is only relative and must include any diminution in growth rate from the most minimal to the most severe. A term such as 'linear retardation of bone growth' would probably be the most correct, or the term 'arrest' as used by many workers. The histological lesions found are analogous to the lines that occur across the fingernails, associated with periods of similar arrest of growth of these structures. They represent a microscopical counterpart to the gross lesions that can be pictured, using shadow-graphs of the calcified cross-bands known as Harris lines, and familiar in the tibia and radius, but they are not just uncalcified Harris lines. Their relation to the radiological picture is discussed at length by Park (1964). We have $x$-rayed many of these rib ends, but, while some lesions can be seen on the film, the finer bands are not shown. There appears also to be a considerable reduction in the rate at which these cross-bands of cartilaginous matrix mineralize in different children.

If a cross-banding can be seen in the rib of a stillborn child, it probably is more significant than a similar evidence of growth arrest in an infant, as it has been repeatedly shown that even a minor infection will produce a greater histological disturbance in the growing bone of an experimental animal than does very severe undernutrition (Schneider and Adar, 1964). It is possible in some cases to find a correlation between the evidence of growth arrest in an infant's rib and a history of obstetric incidents, such as the mother having a motor accident (see Fig. 7) or of an antepartum haemorrhage, but in the majority of cases, the clinical histories available to us are too inadequate to attempt an over-all study.

It is, however, becoming possible to identify some pattern in these cases, such as that of neonatal death following prolonged terminal growth retardation in which the placenta has a very thick decidua. There also seems to be another group with repeated neonatal deaths at about 36 weeks' gestation, and in which the neonatal death is associated with haemorrhage in the brain. In these, there is often evidence in the rib of repeated short phases of growth retardation. It is hoped to report some of these later.

The histological picture of bizarre growth (Fig. 4) is striking, but its significance is much less certain than that of growth retardation. The general appearance is that of overstimulation which could be primary or secondary (Rose, Bradley, and Nelson, 1966). There is an increased thickness in the mass of maturing cartilage cells, but this, as Dodds and Cameron (1934) showed in experimental rickets, does not imply an acceleration of growth but retarded cartilage removal. Both thyroidectomized and ovariectomized guinea-pigs show an early increased proliferation of cartilage; in such conditions growth retardation lies in the later ossification (Silberberg and Silberberg, 1940).

It must be remembered that we are dealing at the moment with pre-bone soft tissue and are not concerned with the effects of growth on true bone cells at all; these are measured in quite different 


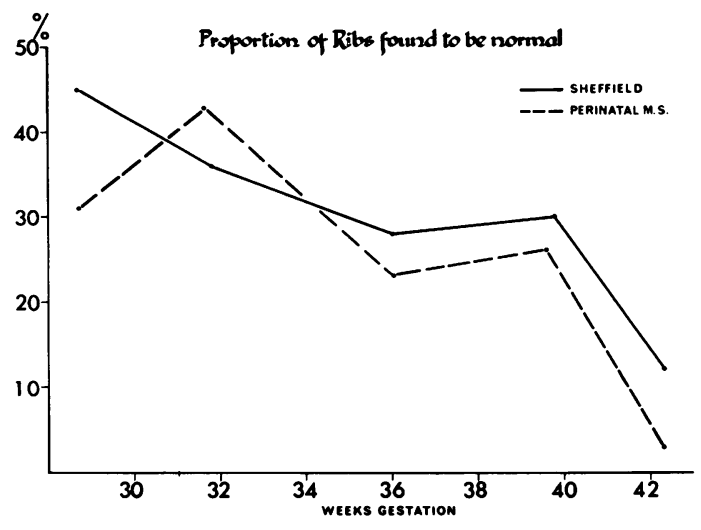

FIG. 9.-The proportion of rib ends showing no evidence of intrauterine growth disorder, related to gestational age at birth. The broken lines are the Perinatal Mortality Survey cases.

ways (Epker and Frost, 1965; Villanueva, Sedlin, and Frost, 1963).

The effect of anterior pituitary growth hormone on guinea-pigs is to promote both proliferation and ossification of cartilage, but these two effects do not run parallel. The bone growth rate and the histological appearance of the active cartilage depends on the balance between these effects
(Silberberg and Silberberg, 1940). Perhaps the most consistent association with increased epiphysial growth is that of local vascularization (Wu and Miltner, 1937), whether due to local inflammation, vascular shunts, local operation, or tumours; but it is difficult to see how this can apply in utero unless there is a general hypovascularity in these children showing growth retardation around term and in so-called 'postmatures', related to the progressive blocking-off of villi in the senile placenta. The bizarre effect is much more like what one would expect with a failure of maturation of an enzyme system as in icterus neonatorum. There has been much recent work on a chondrolytic enzyme, papain, but the changes that we see in the ribs are not similar to those of the effect of papain on cartilage (Engfeldt, Hulth, and Westerborn, 1959; Schneider, 1963).

Incidence of lesions in perinatal deaths. The incidence of abnormal costochondral junctions in the ribs from Sheffield deaths and those obtained through the Perinatal Mortality Survey show a remarkable similarity. The incidence of abnormality and the type of lesions found are shown related to gestation at birth in Fig. 9 and 10.

In the babies of up to 32 weeks' gestation, approximately $40 \%$ showed no abnormal picture.

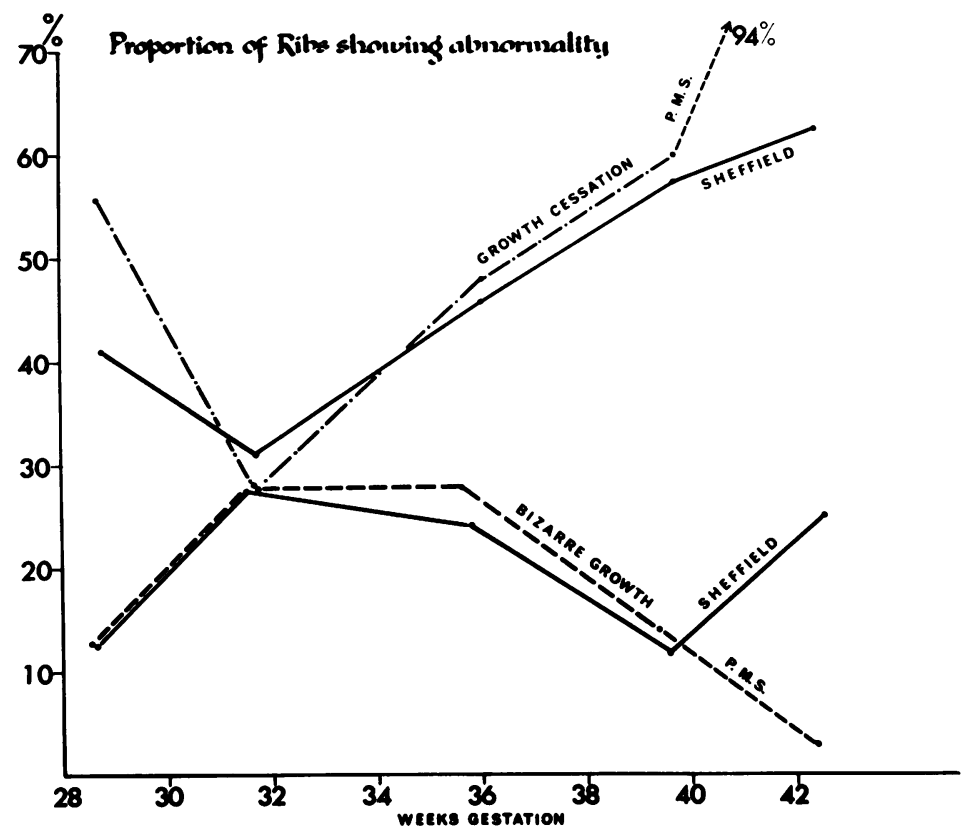

FIG. 10.-The proportion of ribs showing evidence of growth retardation as compared with those showing a bizarre picture related to gestation age. Note the increasing preponderance of simple growth arrest in the more mature babies. 
From that time on, there appeared to be a progressive decrease in incidence of normality to around $25 \%$ at term and $20 \%$ or less in those of prolonged gestation (Fig. 9).

The incidence of arrest of growth is greater than that of bizarre growth at all gestations, and there is increasing relative incidence of growth cessation in the more mature babies. The incidence of both types of lesion is so similar in the Sheffield and outside series as to suggest that the Sheffield 'population' is a representative one.

The changes found in these ribs suggest that, of the children either stillborn or dying within 48 hours of birth, at least two-thirds show evidence of an upset in growth antedating labour. In detail- $60 \%$ of children born at 32 weeks or less show evidence of having been ill in utero before birth, and of those born at term the proportion is around $75 \%$. In one group of children dying at over 40 weeks' gestation, over $90 \%$ showed evidence of growth disorder.

The importance of these findings in assessing the importance of abnormal labour in perinatal deaths is obvious, as also is the relation to 'postmaturity', 'prematurity', or 'dysmaturity' (Sjöstedt, Engleson, and Booth, 1958), and to placental insufficiency, but a discussion of this is not within the scope of this study. It is, however, our belief that a critical assessment of neonatal ribs may help greatly in sorting out some of the factors in these clinical syndromes.

\section{Summary}

A histological study of the costochondral junction has been carried out on a large series of perinatal deaths.

The normal and abnormal appearances of the costochondral junction of the older foetuses are described.

Two types of deformity were found, interpreted as due to growth arrest and to a bizarre form of growth.

The evidence suggests that, of children dying during labour or in the neonatal period, approximately $75 \%$ show evidence of disordered growth in utero before labour has begun.

The histological study of the costochondral junction is an extremely valuable part of the study of any perinatal death.

\section{REFERENCES}

Butler, N. R., and Bonham, G. D. (1961). In national survey of perinatal mortality. First results. Brit. med. f., 1, 1313.

- , and - (1963). Perinatal Mortality. Livingstone, Edinburgh and London.

Cohen, J. (1948). Normal variation of the costochondral junction. Arch. Path., 45, 246.

Dodds, G. S. (1930). Row formation and other types of arrangements of cartilage cells in endochondral ossification. Anat. Rec., 46, 385.

, and Cameron, H. C. (1934). Studies on experimental rickets in rats. Amer. F. Anat., 55, 135.

Emery, J. L. (1957). Proceedings of the Pathological Society of G.B. and I. F. Path. Bact., 74, 244.

- (1964). The assessment of the duration of illness in children unexpectedly dead. Med. Sci. Law, 4, 39.

Engfeldt, B., Hulth, A., and Westerborn, O. (1959). Effect of papain on bone. I. A histologic, antoradiographic, and microradiographic study on young dogs. Arch. Path., 68, 600.

Epker, B. N., and Frost, H. M. (1965). A histological study of remodeling at the periosteal, haversian canal, cortical endosteal and trabecular endosteal surfaces in human rib. Anat. Rec., $152,129$.

Follis, R. H. (1958). Deficiency Disease, p. 13. C. C. Thomas, Springfield, Illinois.

Harris, H. A. (1929). The vascular supply of bone with special reference to the epiphysial cartilage. f. Anat. (Lond.), 64, 3.

- (1933). Bone Growth in Health and Disease. The Biological Principles Underlying the Clinical, Radiological and Histological Diagnosis of Perversions of Growth and Disease in the Skeleton. Oxford University Press, London.

Jackson, C. M. (1924). The Effects of Inanition and Malnutrition upon Growth and Structure. Blakiston, Philadelphia.

McCollum, E. V., Simmonds, N., Shipley, P. G., and Park, E. A. (1922). Studies on experimental rickets. XV. The effects of starvation on the healing of rickets. Bull. fohns Hopk. Hosp., 33, 31 .

Park, E. A. (1954). The influence of severe illness on rickets. Arch. Dis. Childh., 29, 369.

- (1964). The imprinting of nutritional disturbances on the growing bone. Pediatrics, 33, 815.

—, and Richter, C. P. (1953). Transverse lines in bone; the mechanism of their development. Bull. Fohns Hopk. Hosp., 93, 234.

Pratt, C. W. M., and McCance, R. A. (1960). Severe undernutrition in growing and adult animals. 2. Changes in the long bones of growing cockerels held at fixed weights by undernutrition. Brit. F. Nutr., 14, 75.

Rose, S., Bradley, T. R., and Nelson, J. F. (1966). Factors influencing the growth of epiphyseal cartilage. Aust. F. exp. Biol. med. Sci., 44, 57.

Schneider, M. (1963). Experimental epiphyseal arrest by intraosseous injection of papain. 7 . Bone $7 t$ Surg., 45-A, 25.

cartilage plates. Arch. Path., 78, 149.

Silberberg, M., and Silberberg, R. (1940). The effect of thyroidectomy and administration of anterior pituitary extract of cattle on the growth of cartilage and bone of immature guinea pigs. Amer. F. Path., 16, 505.

Sjöstedt, S., Engleson, C., and Booth, G. (1958). Dysmaturity. Arch. Dis. Childh., 33, 123.

Villanueva, A. R., Sedlin, E., and Frost, H. M. (1963). Variations in osteoblastic activity with age by osteoid seam index. Anat. Rec., 146, 209.

Wersch, H. J. Van (1954). Scurvy as a Skeletal Disease. Dekker \& Van de Vegt, Utrecht-Nijmegen.

Wu, Y. K., and Miltner, L. J. (1937). A procedure for stimulation of longitudinal growth of bone. f. Bone ft Surg., 19, 909. 